\title{
Current status of the rare British endemic Gentianella amarella subsp. occidentalis, Dune Gentian (Gentianaceae)
}

\author{
Lyn D.I. Evans ${ }^{1 *} \&$ Timothy C.G. Rich ${ }^{2}$ \\ ${ }^{1}$ Department of Countryside Management, Bridgend College, U.K; ${ }^{2}$ Cardiff, U.K.
}

*Corresponding author: Lyn Evans lynevans85@gmail.com

This pdf constitutes the Version of Record published on $26^{\text {th }}$ July 2021

\begin{abstract}
Gentianella amarella subsp. occidentalis, Dune Gentian, is a rare annual of dune slacks endemic to Western Britain. Its current status was compared to historic records. A maximum of 2250 plants were found in ten subpopulations in four sites in 2019-2020. It was not refound in three sites and 15 subpopulations. It is assessed as IUCN threat category 'Endangered'. Its primary vegetation type is SD14d Salix repens - Campylium stellatum dune slack Festuca rubra subcommunity, within which it favours short, open structure on dry, low nutrient soils. Conservation requires managing and creating its niche in the dune slacks.
\end{abstract}

Keywords: Dune slack; Endangered; England; IUCN threat criteria; Wales.

\section{Introduction}

Gentianella amarella subsp. occidentalis T.C.G. Rich \& McVeigh, Dune Gentian, is a small, summer annual of dune slacks endemic to South Wales and North Devon in Western Britain (Rich \& McVeigh, 2019; Stace, 2019; Figs. 1 \& 2). Historically referred to as Gentianella uliginosa (Willd.) Börner in Britain, it was recently recognised as a morphologically distinct taxon related to the biennial $G$. amarella subsp. amarella (Rich et al., 2018). A short video showing the plant and its habitat prior to the work reported here is given by Rich (2019).

Rich \& McVeigh (2019) noted Dune Gentian had been recorded from seven sites in four vice-counties (North Devon, Glamorgan, Carmarthenshire and Pembrokeshire) and gave its IUCN threat category as 'Vulnerable'. Following concern that it was declining, a comprehensive survey of all its sites in 2019-2020 was undertaken, its IUCN threat category re-assessed, the habitat described and recommendations made for its conservation. The results are summarised here; fuller details are given in Evans (2020).

\section{Methods}

Historical data on its distribution, abundance and habitat were compiled from herbaria (ABD, BIRM, BM, CGE, HDD, K, LTR, NMW, OXF, RNG), literature, the BSBI Distribution Database (https://database.bsbi.org/, accessed January 2019), Aderyn/LERC Wales (accessed January 2019) and data held by Natural Resources Wales. The population counts from the last 50 years presented in the figures have been compiled from Vaughan et al. (1972), Elias (1981), Youngson (1986), Jones 
(1992, 1993, 1994), Kay \& John (1995), Rich (2004), Dockerty (2010), the BSBI database and our personal observations.

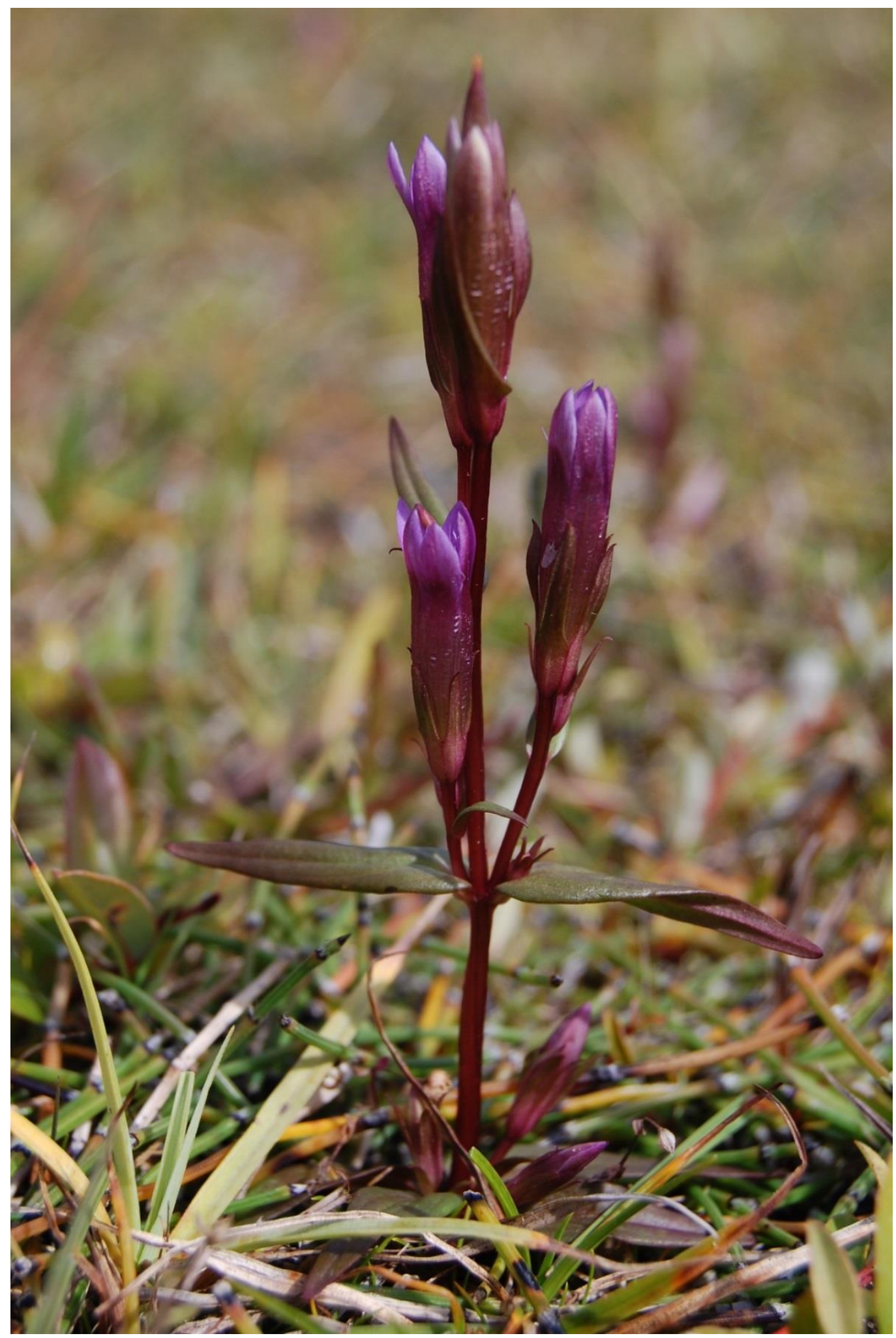

Figure 1. Gentianella amarella subsp. occidentalis. 


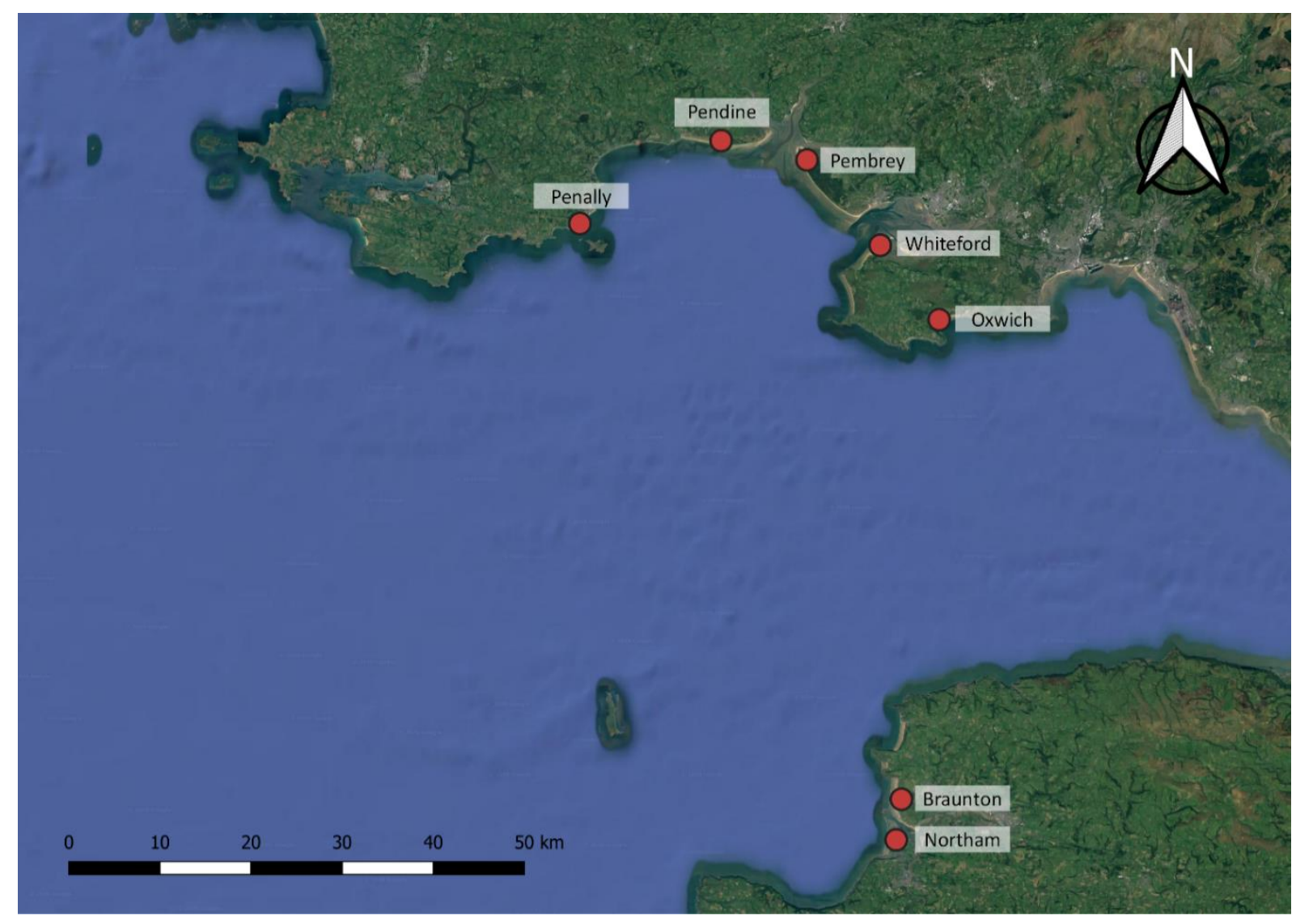

Figure 2: Sites from which Gentianella amarella ssp. occidentalis has been recorded. Basemap @ Google maps

L. Evans with the help of M. Breeds, N. Ferris, R. Harding, T.C.G. Rich and J. Woodman searched all sites except for one subpopulation in August and September 2019, and most of the Welsh sites were searched again in August and September 2020 including the missing subpopulation. Populations were counted by careful searching, and taking care to distinguish plants from $G$. amarella subsp. amarella with which it often grows (Rich \& McVeigh, 2019). Hybrids reported as G. amarellax uliginosa are no longer accepted and most such plants are depauperate subsp. amarella (Rich \& McVeigh, 2019).

IUCN $(2001,2019)$ threat categories were determined by assessing the site and population data against the IUCN criteria, using the highest recent population count where two counts were available. Estimates of extent and occupancy were calculated using MAGIC maps (DEFRA, 2013).

Vegetation data were recorded using $2 \times 2$ m quadrats following the NVC protocol but also with percentage cover (Rodwell, 2000, 2006). Additional quadrats from surrounding dune slacks and slopes approximately $1 \mathrm{~m}$ altitude above and below the Gentianella population were recorded to provide comparative data. NVC community types were allocated using the floristic tables and keys in Rodwell (2000) and 'MAVIS' software (Smart, 2000).

Ellenberg indicator values (Hill et al., 2004) were calculated for each quadrat in MAVIS. Mean values were calculated by combining quadrat data at, below and above the level of the target species; these values were analysed using one-way ANOVA to determine which variables differed significantly. Ellenberg values for each 
population were compared to those derived from the 'standard' associated NVC community data from Rodwell (2000); as the NVC tables give Domin scores, percentage cover required by MAVIS was calculated by taking the median Domin value from the cited range and calculating (Domin) $)^{2.6} / 4$ to correct for underestimation of the means (Currall, 1987).

Vascular plant nomenclature follows Stace (2019). NVC types follow Rodwell (2006).

\section{Results}

Population sizes

1. Braunton Burrows (v.c.4)

It was first collected at Braunton Burrows in 1843 but was only rediscovered recently (Holyoak, 1999). It been recorded as widely distributed in five slacks but never in quantity; Holyoak (1999) recorded 'over 130 plants', BSBI records mention 'several plants' and an unpublished Natural England report from 2012 states 'half a dozen plants'. In 2019, a total of 43 plants were found in four slacks, again all in small quantity (Table 1) including two new subpopulations. It was not refound in three historic subpopulations (one slack was suitable but two were not) giving a total of seven locations within the Burrows.

\section{Northam Burrows (v.c.4)}

It was only recorded once at Northam Burrows in 1882 (Rich, 1996). No plants were found in 2019 or on three previous searches by T. Rich 2004-2008. Northam Burrows is now a golf course and only one small slack remains with generally unsuitable habitat.

\section{Oxwich Bay (v.c.41)}

It was first recorded at Oxwich in 1927 and subpopulations have been recorded at up to seven slacks (Lousley, 1950; Kay, 1973; Elias, 1981; Table 1). The recent population data traced are summarised in Fig. 3. Jones (1994) noted populations recorded by Morgan (1988) in three slacks had gone by 1993. In the early 1990s, the large population in Slack 21 was nearly destroyed by construction of a dune scrape (Q.O.N. Kay, pers. comm. 1995); it has taken over 20 years for this population to recover.

In 2019, one good population of 478 plants was found on the scraped edges of Slack 21, with a few isolated plants in the centre. In 2020, 998 plants were present (Table 1). The six slacks with historic records now all have coarse vegetation or scrub and no plants were found in them.

\section{Whiteford Burrows (v.c.41)}

It was first recorded at Whiteford in 1934 and has been recorded in at least seven widely distributed slacks (Lousley, 1950; Kay, 1973; Table 1). In 2019, 280 plants were found in four slacks, with over two-thirds of the population in Slack 19. Slacks 7 and 9, which had records of several hundred plants in 2003-2004, had only several dozen plants despite having suitable habitat at the time of survey. At Slack 60 where it was recorded as 'occasional' in 2015, one diminutive plant was found. In 2020, a total of $c .1200$ plants were found in Slacks 9 and 19, the latter again with the largest subpopulation. Many of the slacks on the east side of the dunes with records from 
the 1970s have scrubbed over with Salix spp. and Betula pubescens. The recent population data traced are summarised in Fig. 4.

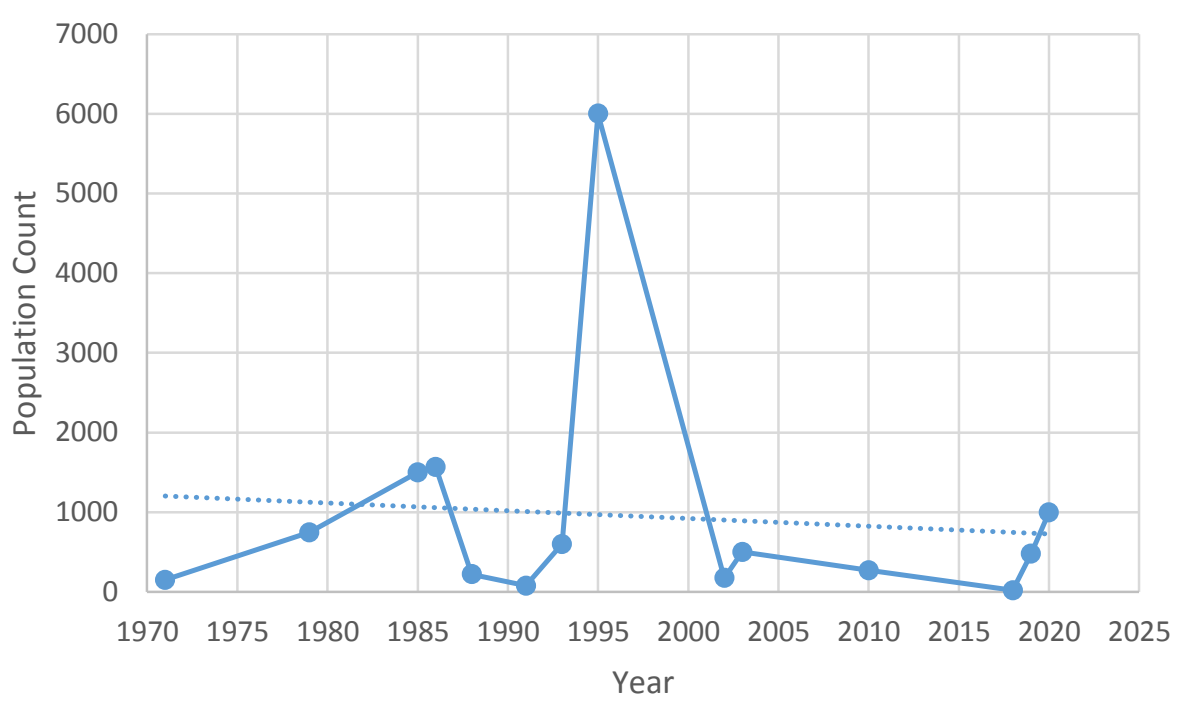

Figure 3. Population counts of Gentianella amarella subsp. occidentalis at Oxwich. A trend line (dotted) is also given.

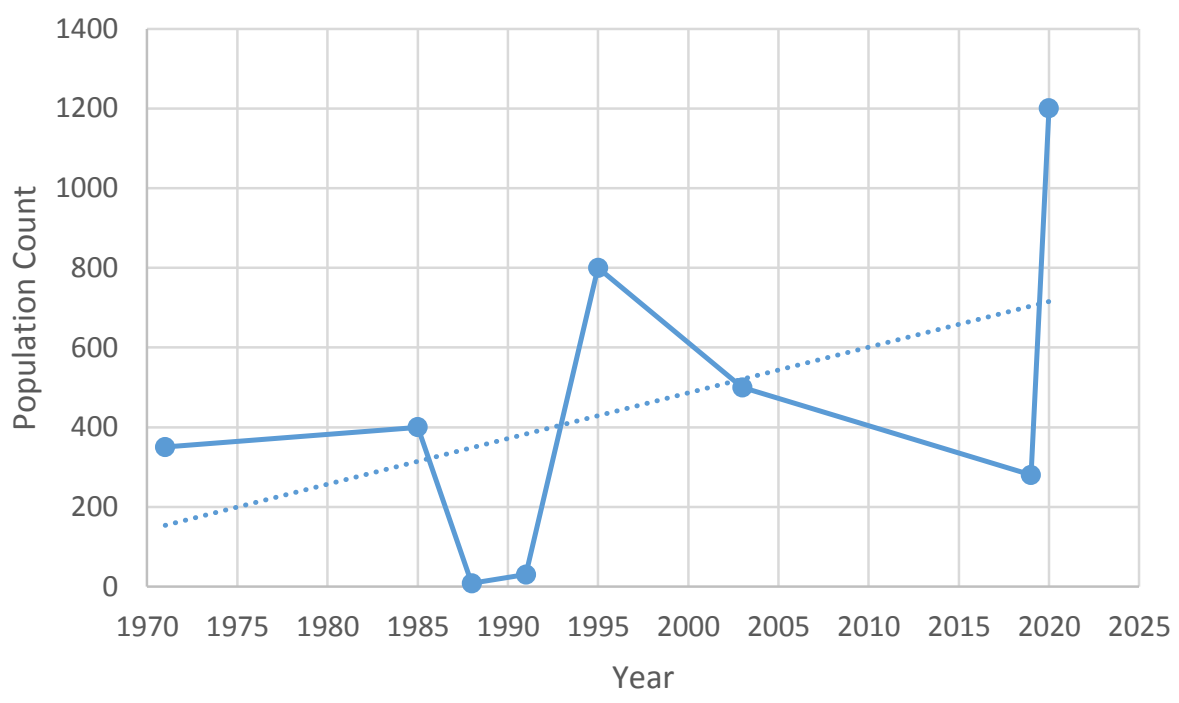

Figure 4. Population counts of Gentianella amarella subsp. occidentalis at Whiteford. A trend line (dotted) is also given.

5. Pendine Burrows (v.c.44)

It was first recorded at Pendine in 1944 (Vaughan et al., 1972) and has occurred in two locations, on tractor ruts in a slack and beside a test track. A possible third subpopulation at SN284072 (Jones, 1993) has not been confirmed and no plants were found there in 2020. It was last recorded in 1992 when seed was collected and no plants were reported in 1993 (Jones, 1994).

In 2019 and 2020, no plants were found; the slack has become unsuitable with coarse slack vegetation (though there had been some recent scrub clearance) and the test track has only a modicum of suitable slack vegetation. 


\section{Pembrey Burrows (v.c.44)}

It was first recorded at Pembrey in 1961 and has been recorded at three locations. The recent population data traced are summarised in Fig. 5. In 2019, only nine plants were found in an area of short turf, which had seven plants in 2020 (Table 1). It was not re-located on a trackway where previously noted as 'occasional' and where suitable habitat was present, or the helipad where it was frequent in 2003 but was dominated by coarse vegetation in 2019.

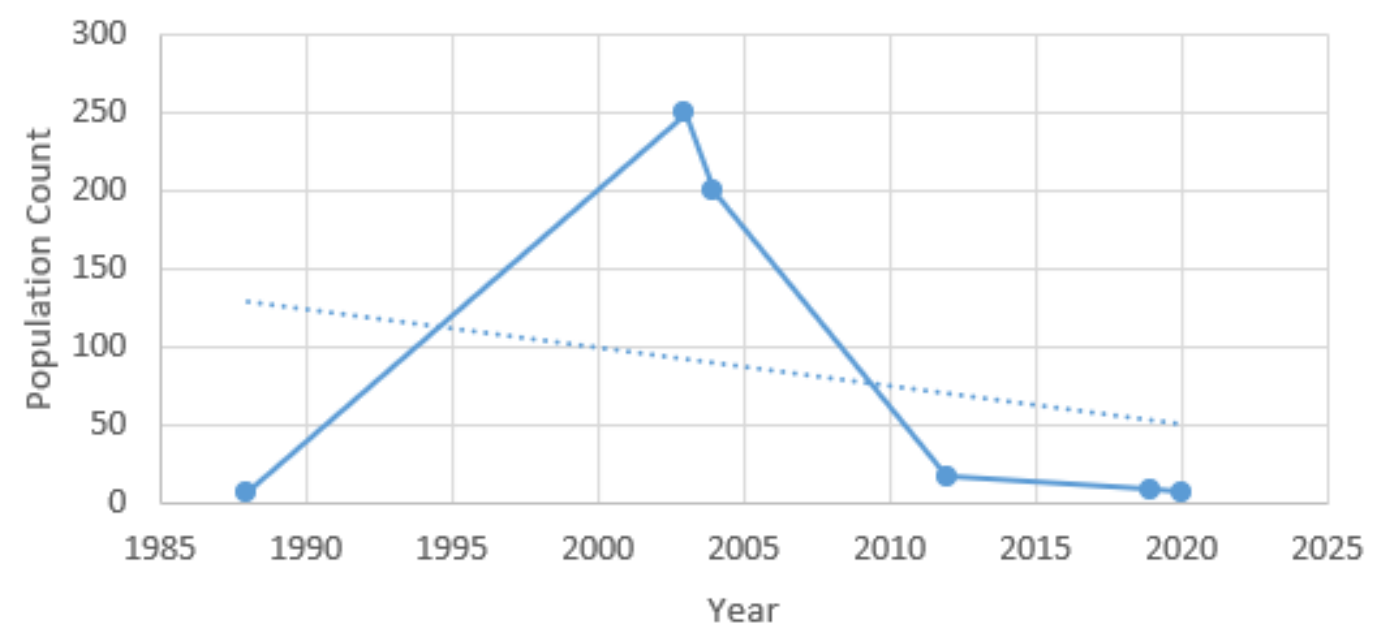

Figure 5. Population counts of Gentianella amarella subsp. occidentalis at Pembrey. A trend line (dotted) is also given.

\section{Penally Burrows, Tenby (v.c.45)}

It was first recorded at Penally in 1923 and was recorded in damp sandy pastures and a dune slack; the former may have been destroyed by construction of the golf course in 1946 and by 1950 and 1971 was restricted to one slack (Pugsley, 1924; Lousley, 1950; Vaughan et al., 1972). A population of 58 plants was recorded in 1993 (Jones 1994) and it was last recorded in 1994. The population data traced are summarised in Fig. 6.

No plants were found in five visits 2004-2020. The slack from where it was most recorded has become dominated by rank grass and scrub, although parts of the slack had been partially scraped off in c.2016 in a possible attempt to restore the habitat. Grass and scrub cuttings seem to have been regularly dumped by the slack for many years which may have contributed to the changes in the vegetation.

Population fluctuations are difficult to estimate based on historical data and our survey results, but some indication of fluctuations are shown in Figs. 3-6. In 2020 in Welsh sites there were nearly three times as many plants as in 2019 showing some fluctuations from year to year (Table 1). Jones (1999) also noted that it appears to be sensitive to climatic conditions and may disappear or occur in low numbers during wet and cool summers and can reappear in abundance in warm years.

In summary, in 2019-2020 a maximum total of c.2250 plants were recorded in four sites in ten subpopulations and it was not recorded in three former sites or 15 subpopulations (Table 1). 


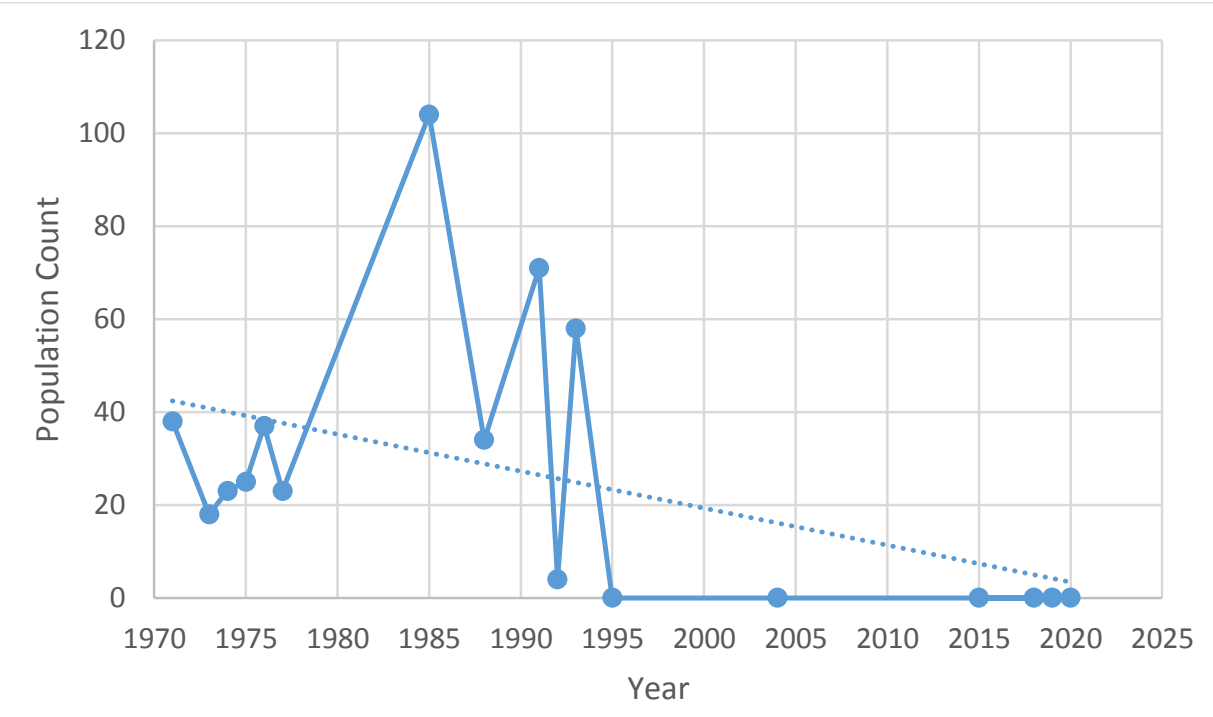

Figure 6. Population counts of Gentianella amarella subsp. occidentalis at Penally. A trend line (dotted) is also given.

\section{IUCN threat category}

IUCN (2001) Criterion A considers a reduction in population sizes. This is difficult to quantify as the historical records are mainly sporadic, site specific and incomplete. Our population counts varied threefold between 2019 and 2020, which is consistent with the peaks and troughs historically recorded at individual sites (Figs. 3-6). Youngson (1986) estimated the Welsh populations as 2064 plants. An estimate of the Welsh populations 1991-1993 from the combined data in Jones (1992, 1993, 1994 ) is $215+$ plants. Kay and John (1995) gave estimates of the Welsh populations as 4000-8000 plants at Oxwich, 600-1000 plants at Whiteford and 40+ plants at Pendine, suggesting (using mid-range values) a population of $c .6840$ (we have some concerns about the accuracy of these estimates, though it may have been an exceptional year). However, it is clear that all sites in South Wales have lost subpopulations and a significant ten year decline seems very likely (Figs. 3-6; Table 1). It is difficult to assess trends at Braunton from the fragmentary data.

IUCN (2001) Criterion B1 considers the geographic range. The extent of occurrence is defined as the smallest imaginary boundary drawn between all known sites (IUCN, 2001, 2019). A degree of subjectivity was involved in estimating extent; a generous boundary gave an extent of $1100 \mathrm{~km}^{2}$ while a frugal boundary gave an extent of $130 \mathrm{~km}^{2}$; both figures place it between $100 \mathrm{~km}^{2}-5000 \mathrm{~km}^{2}$ which equates to the 'Endangered' category. The population is highly fragmented and is currently known from four sites. It is subject to continued decline based on (i) a reduction in extent of occurrence as a result of being lost from the Penally and Pendine sites in recent years; (ii) a decline in area of occupancy as a result of being lost from the Penally and Pendine sites; (iii) decline in quality of suitable habitat, particularly as a result of scrub encroachment on sites across South Wales; and (iv) a decline in the number of subpopulations, particularly at Oxwich and Whiteford, qualifying it as 'Endangered'. 
Table 1. Population counts of Gentianella amarella subsp. occidentalis for all sites surveyed 2019-2020.

\begin{tabular}{|c|c|c|c|c|}
\hline Site & Subpopulation & $\begin{array}{l}\text { No. } \\
\text { plants } \\
2019\end{array}$ & $\begin{array}{l}\text { No. } \\
\text { plants } \\
2020\end{array}$ & $\begin{array}{l}\text { Maximum } \\
\text { total per } \\
\text { site }\end{array}$ \\
\hline \multirow[t]{8}{*}{ Braunton Burrows } & Beach Head Slack & 3 & - & \\
\hline & Beach Head Slack north a & 0 & - & \\
\hline & Beach Head Slack north b & 0 & - & \\
\hline & Bush grass Slack & 0 & - & \\
\hline & Partridge Slack & 21 & - & \\
\hline & Pebble Slack & 6 & - & \\
\hline & Pine Slack & 13 & - & \\
\hline & & & & 43 \\
\hline \multirow[t]{2}{*}{ Northam Burrows } & Northam Burrows & 0 & - & \\
\hline & & & & 0 \\
\hline \multirow[t]{8}{*}{ Oxwich } & Slack 11/Near Slack 9 & 0 & 0 & \\
\hline & Slack $16 / 18$ & 0 & 0 & \\
\hline & Slack 20 & 0 & 0 & \\
\hline & Slack 21 (new scrape) & 478 & 998 & \\
\hline & SW of Slack 21 & 0 & 0 & \\
\hline & Slack 31 & 0 & 0 & \\
\hline & Slack 39 & 0 & 0 & \\
\hline & & & & 998 \\
\hline \multirow[t]{4}{*}{ Pembrey } & Helipad & 0 & - & \\
\hline & South of targets & 9 & 7 & \\
\hline & Targets by track & 0 & - & \\
\hline & & & & 9 \\
\hline \multirow[t]{2}{*}{ Penally Burrows } & Golf course Slack & 0 & 0 & \\
\hline & & & & 0 \\
\hline \multirow[t]{3}{*}{ Pendine } & Slack C9 & 0 & 0 & \\
\hline & Slack E4 & - & 0 & \\
\hline & & & & 0 \\
\hline \multirow[t]{8}{*}{ Whiteford } & Slack 7 & 54 & 0 & \\
\hline & Slack 9 & 23 & $c .100$ & \\
\hline & Slack 19 & 202 & C.1100 & \\
\hline & Slacks $20-28$ & 0 & 0 & \\
\hline & Slack 43 & 0 & 0 & \\
\hline & Slack 60 & 1 & 0 & \\
\hline & Slack 94 & 0 & 0 & \\
\hline & & & & $c .1200$ \\
\hline $\begin{array}{r}\text { Maximum total all } \\
\text { sites }\end{array}$ & 28 sites & & & $c .2250$ \\
\hline
\end{tabular}

IUCN (2001) Criterion B2 also considers the geographic range using area of occupancy, defined as the area of suitable habitat from which the taxon is currently 
known (IUCN, 2001, 2019). The area of occupancy was measured as $9.24 \mathrm{~km}^{2}$ by measuring the area of the sand dune systems at its current four sites. When combined with a continued decline in (i) extent of occurrence; (ii) area of occupancy; (iii) quality of habitat; and (iv) number of subpopulations, this qualifies as 'Endangered'.

IUCN (2001) Criterion C considers the population sizes coupled with decline. With only c. 2250 plants recorded in 2019-2020, it is classified as 'Endangered', the threshold for which is fewer than 2500 individuals coupled with an observed or projected population decline. Given the loss of the plant from several sites and numerous subpopulations and the declines indicated in Figs. 3, 5 and 6, it seems likely that losses of significant magnitude have taken place in recent decades.

IUCN (2001) Criterion D deals with very small or restricted population sizes. A maximum population size of c. 2250 plants qualifies it as 'Vulnerable' in this category.

IUCN (2001) Criterion E concerns population projections and the likelihood of extinction in the wild. Fig. 7 shows the overall population sizes in South Wales where comparable data across sites is available. As this is based on only six data points and there is some uncertainty over the Kay \& John (1995) population estimates it requires cautious interpretation. There is little evidence of a general decline over the last 30 years but it is clear individual sites and subpopulations are declining or have disappeared (as above). There is not enough data to predict when, in the absence of conservation measures, it could become extinct.

Based on our data, under Criteria A, B and C, G. amarella subsp. occidentalis clearly qualifies as IUCN (2001) threat category 'Endangered'.

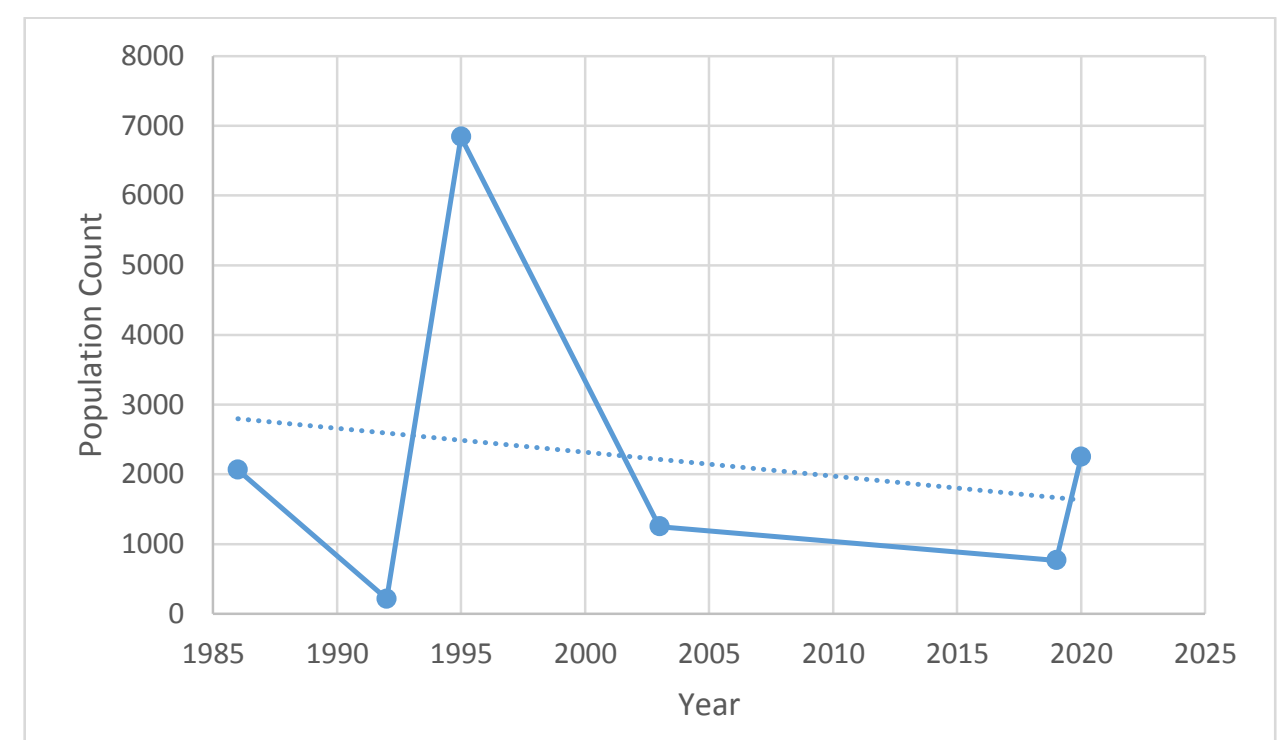

Figure 7. Total population counts of Gentianella amarella subsp. occidentalis from Welsh sites only. A trend line (dotted) is given.

\section{Vegetation}

The species associated with $G$. amarella subsp. occidentalis at constancies of V, IV and III (cf. Rodwell, 2006, i.e. occurring in more than $40 \%$ of the quadrats, ) are summarised in Table 2; another 12 species were recorded at constancy II and 49 species at constancy I. The vegetation was short (average vegetation height $3.4 \mathrm{~cm}$ 
$\pm 1.62 \mathrm{~cm}$ s.d., range $1-7 \mathrm{~cm}$ ), open (average cover of $93.3 \% \pm 8.76 \%$ s.d., range $75-100 \%$ ) and species-rich (average number of species per quadrat of $25.9 \pm 4.22$ s.d., range 16-33 species). The associated species included a few short-lived plants like $G$. amarella subsp. amarella and Linum catharticum which occur in the open gaps between the perennials.

During the surveys it was noticed that there may be a pattern of stratification within the slacks; small colonies and some isolated plants of G. amarella subsp. occidentalis occurred at the lowest points in a number of dune slacks where frequent associates included Epipactis palustris, Hydrocotyle vulgaris, Lysimachia tenella and Pulicaria dysenterica. The more extensive colonies occurred in marginally drier areas with species more associated with dune slopes including Hypochaeris radicata, Rhinanthus minor and Rubus caesius.

In terms of British Plant Communities (Rodwell, 2000), the data indicated that in South Wales G. amarella subsp. occidentalis occurs in the SD14d Salix repensCampylium stellatum dune slack Festuca rubra subcommunity. At Braunton Burrows it occurred in the grassier, older and drier dune slacks with an affinity to both SD14d and to SD16 Salix repens-Holcus lanatus community which had low Salix repens cover and could not be clearly allocated to a subcommunity.

As G. amarella subsp. occidentalis is a summer annual, plants must occupy a narrow niche within the dune slack where plants can germinate, establish, flower and fruit within a temporally variable habitat whose major variable is water table. The ecological factors were therefore characterised further using Ellenberg indicator values for the quadrats (Hill et al., 2004; Table 3). Moisture levels lay between 'moist site' and 'damp site' on the Ellenberg scale. 'Nitrogen', a proxy for soil fertility, indicated the quadrats were located on 'more or less infertile sites'. Light values fell between the definitions 'plant generally in well-lit places, but also occurring in partial shade' and 'light-loving plant rarely found where illumination in summer is less than $40 \%$ ', but as no plants were found in former sites which were now shaded by scrub, light is obviously important overall. Reaction values, a measure of soil $\mathrm{pH}$, were between 'moderately acid soils' and 'weakly acid to weakly basic'. There was no indication of any saline influence in the vegetation in which it occurred.

By comparing Ellenberg values for quadrats with $G$. amarella subsp. occidentalis with quadrats without it from adjacent vegetation at altitudes $c .1 \mathrm{~m}$ above and below, the key factors were indicated to be Moisture $(F=5.47 ; p=0.01)$ and Nitrogen $(F=13.56 ; p=0.0001)$, both well known to be important factors for controlling the occurrence of dune slack vegetation (Rodwell, 2000). Light $(F=1.43$; $\mathrm{p}=0.26)$ and Reaction $(\mathrm{F}=0.55 ; \mathrm{p}=0.58)$ values were not significantly different between vegetation supporting $\mathrm{G}$. amarella subsp. occidentalis and adjacent vegetation without it.

The Ellenberg values were also compared against the values calculated for the 'standard' SD14d Salix repens-Campylium stellatum dune slack Festuca rubra subcommunity and the SD16 Salix repens-Holcus lanatus community (Rodwell, 2000; Table 3). The Moisture value for the G. amarella subsp. occidentalis quadrats was 0.9 points lower than the SD14d standard sub-community (Table 3), suggesting that it occurs in areas that are atypically dry, and lies much closer to that of SD16 than SD14d, with SD16 being associated with older and drier dune slacks as at Braunton (Rodwell, 2000). There is much less variability in Nitrogen values than for moisture (Table 3), which is to be expected in a sand dune system low in available nutrients 
(Grootjans et al., 1998), though G. amarella subsp. occidentalis lies over half a point lower than the standard SD14d community and almost a point lower than the SD16 standard community with which it more closely aligns on Moisture value. The Light and Reaction values are very similar (Table 3).

Table 2. Species associated with Gentianella amarella subsp. occidentalis in 16 quadrats (5 at Braunton, 5 at Oxwich, 2 at Pembrey and 4 at Whiteford).

\begin{tabular}{|l|c|}
\hline Species & Constancy \\
\hline Gentianella amarella subsp. occidentalis & $\mathrm{V}$ \\
\hline Carex flacca & $\mathrm{V}$ \\
\hline Festuca rubra & $\mathrm{V}$ \\
\hline Gentianella amarella subsp. amarella & $\mathrm{V}$ \\
\hline Leontodon saxatilis & $\mathrm{V}$ \\
\hline Linum catharticum & $\mathrm{V}$ \\
\hline Lotus corniculatus & $\mathrm{V}$ \\
\hline Prunella vulgaris & $\mathrm{V}$ \\
\hline Salix repens & $\mathrm{V}$ \\
\hline Equisetum variegatum & IV \\
\hline Euphrasia spp. & IV \\
\hline Hydrocotyle vulgaris & IV \\
\hline Leontodon hispidus & IV \\
\hline Agrostis stolonifera & III \\
\hline Carex viridula & III \\
\hline Danthonia decumbens & III \\
\hline Epipactis palustris & III \\
\hline Holcus lanatus & III \\
\hline Homalothecium lutescens & III \\
\hline Lysimachia tenella & III \\
\hline Mentha aquatica & III \\
\hline Polygala vulgaris & III \\
\hline Pulicaria dysenterica & III \\
\hline Ranunculus flammula & III \\
\hline Rubus caesius & III \\
\hline Trifolium pratense & III \\
\hline Trifolium repens & III \\
\hline
\end{tabular}

\section{Discussion}

The total world population of G. amarella subsp. occidentalis comprised only c.2250 plants in 2019-2020. It occurred in only ten subpopulations in four sites. Whilst declines are difficult to quantify due to varied historical recording, the data suggests that it has declined in both populations and sites since the 1970s and it was not refound in three sites and 15 subpopulations. The decline noted by Jones (1994) has continued with the loss of the Penally and Pembrey sites, and it must now be regarded as IUCN (2001) threat category 'Endangered'. 
Table 3. Ellenberg indicator values (Hill et al., 2004) of Gentianella amarella subsp. occidentalis quadrats compared with those for SD14d Salix repensCampylium stellatum dune slack Festuca rubra subcommunity and SD16 Salix repens-Holcus lanatus community.

\begin{tabular}{|l|c|c|c|}
\hline $\begin{array}{l}\text { Ellenberg } \\
\text { Indicator }\end{array}$ & $\begin{array}{l}\text { Mean value ( } \\
\text { SD) subsp. } \\
\text { occidentalis } \\
\text { quadrats }\end{array}$ & $\begin{array}{l}\text { Mean value for } \\
\text { SD14d } \\
\text { community }\end{array}$ & $\begin{array}{l}\text { Mean value for } \\
\text { SD16 } \\
\text { community }\end{array}$ \\
\hline Moisture & $6.03( \pm 0.64)$ & 6.9 & 6.2 \\
\hline Nitrogen & $3.16( \pm 0.30)$ & 3.7 & 4.0 \\
\hline Light & $7.52( \pm 0.17)$ & 7.5 & 7.4 \\
\hline Reaction & $6.11( \pm 0.17)$ & 6.3 & 6.3 \\
\hline
\end{tabular}

The decline has occurred despite it having had statutory protection (as Gentianella uliginosa auct. angl.) for years. It is protected under Schedule 8 of the Wildlife and Countryside Act 1981 as amended, is a Section 41 Species of Principal Importance under the Natural Environment and Rural Communities Act 2006 in England, a Section 7 Species of Principal Importance in Wales under the Environment (Wales) Act 2016 in Wales and a Red Data Book species (Wigginton, 1999). The decline has also occurred despite it being listed as a feature in the SSSI schedules for all of its recent sites (Braunton Burrows SSSI, Oxwich Bay SSSI, Whiteford Burrows, Landimore Marsh and Broughton Bay SSSI, Pembrey Coast SSSI, Laugharne-Pendine Burrows SSSI and Lydstep Head to Tenby Burrows SSSI; it was probably long gone before Northam Burrows SSSI was designated). Furthermore, the Whiteford and Oxwich populations are within National Nature Reserves, the Braunton Burrows population is within a Biosphere Reserve, and the Whiteford, Pembrey, and Pendine Burrows sites are within the Carmarthen Bay Dunes Special Areas of Conservation. Such designations may have provided general protection to the sites (though the Oxwich population was nearly destroyed by scraping its slack in the early 1990s), but have not maintained the specific ecological niche it requires.

A refocus on maintaining and creating appropriate growth conditions is clearly required so the habitats have been characterised. The vegetation analysis showed the primary ecological niche is the SD14d Salix repens-Campylium stellatum dune slack Festuca rubra subcommunity. This species-rich vegetation type occurs in slacks of moderate age that are neither newly formed nor long-established and shares many of its characteristics with species-rich fens (Rodwell, 2000; Proctor, 2013). It is an uncommon community - in Wales only occurring extensively at ten sites - which supports 18 rare or scarce plants including dune slack specialities such as Liparis loeselii and Teucrium scordium (Rhind \& Jones, 1999; Rodwell, 2000; Blackstock et al., 2010).

However, whilst both the soil Moisture and Nitrogen Ellenberg values are important in determining its niche, they do not seem to be entirely typical of SD14d vegetation. Whilst the gentian requires reasonable levels of moisture, as would be expected from a dune slack species (Grootjans et al., 2004), the Ellenberg values indicate it favours slightly drier soils than 'typical' SD14d; with some of the largest subpopulations occurring within drier slacks or towards the edge of mechanical scrapes. This may account for the similarities to the SD16 community, which tends 
to occur in drier slacks further along the successional sequence (Rodwell, 2000). A 'grassy look' to the sward is used to describe both SD14d and SD16 which is typical of many of the communities surveyed, but the low Salix repens scrub which typifies SD16 and to a lesser extent SD14 is not a feature of the G. amarella subsp. occidentalis niche in which the mean vegetation height was only $3.4 \mathrm{~cm}$.

Soil fertility seems to be a major factor and it favours areas that are less fertile than are typical of the communities. As it favours nutrient-poor soils, it is possible that atmospheric nitrogen deposition may have had a long-term impact on some sites. Nitrogen deposition in dune slacks is thought to have a limited effect on the vegetation (Jones et al., 2004), though studies at Braunton Burrows showed that dune vegetation responds to increased nitrogen levels (Willis, 1963). Nutrient enrichment also results from the accumulation of organic matter associated with sand-dune succession (Olff et al., 1993) or accumulation of biomass from a lack of grazing.

Local factors within the vegetation may also play a role in determining the gentian's niche. Many of the populations surveyed occurred near trackways, paths or where mechanical groundwork had been undertaken and its clearly prefers open ground. Such ground disturbance is usually favourable to annuals (Kleyer, 1999), such as $G$. amarella subsp. occidentalis, and should be considered as part of future management.

Longer term, management is also key to maintaining populations and its niche. Rabbit grazing was evident at all extant populations and the close-cropped sward that they produce is important to maintaining the open vegetation. Where rabbit numbers have been reduced in the past, for example by myxomatosis at Braunton, there has been a marked decline in the richness of dune vegetation (Breeds \& Rogers, 1998). However, rabbits are only likely to be able to maintain suitable conditions when used in conjunction with other grazing animals that are more effective at removing coarser vegetation (Rhind \& Jones, 2009; Ausden, 2007). Lack of management has resulted in Salix and Betula scrub encroachment and many South Wales slacks are now in the latter successional stages, and accounts for declines such as at Oxwich. Maintaining the present vegetation and niche around the largest remaining populations at Oxwich and Whiteford is thus critical. Habitat restoration is also required and should focus on areas where $G$. amarella subsp. occidentalis was recently known to occur or slacks near to existing populations. There is a clear need for experimental management work to be undertaken under field conditions as has been done for Liparis loeselii which appears to occupy a similar niche (Jones, 1998; Carrington et al. 2010).

At a landscape scale, the dune slack habitats are created by natural processes, progressing over periods of 20-60 years from pioneer slacks to mature slacks before being lost to succession (Grootjans et al., 2002, 2004). The Dune Gentian and other rare plants are dependent on this dynamic system allowing maintenance of metapopulations, but dune systems have become less dynamic in the last 60-70 years as a result of changes in both climate and management (Pye et al., 2013) and it is uncertain that the processes will continue to create adequate suitable habitat in the future. Species-rich dune slack communities can be both maintained and reestablished through judicious management (Sýkora et al., 2004). The 'Sands of LIFE' project (Natural Resources Wales, 2021) aims to recreate natural movement in and rejuvenate habitats in ten Welsh dunes sites 2018-2022 including the Pembrey, 
Pendine and Whiteford sites, which may indirectly benefit $G$. amarella subsp. occidentalis in the long term which is not specifically included in the project.

Gentianella amarella subsp. occidentalis has no obvious adaptation to seed dispersal and the life of its seed bank (cf. Jones, 1999) is unknown, so local seed reintroductions could be considered should populations continue to decline. Five small seed collections are held in the Millennium Seed Bank from Oxwich (1967, 1992), Penally (1992), Pendine (1992) and Pembrey (1974) (S. Miles, pers. comm. 2021) and new collections from Braunton and Whiteford would be a priority to collect. Although Gentianella taxa are notoriously difficult to grow from seed, possibly due to a dependency on specific vesicular-arbuscular mycorrhizae, $\mathrm{T}$. Rich was able to grow one collection of $G$. amarella subsp. occidentalis (collected under licence) from Oxwich to fruit set using the sand from the dune slack so it may be possible to bulk up seed stocks for reintroduction and management programmes.

\section{Acknowledgements}

We thank Mary and John Breeds, Simon Caporn, Stephen Evans, Natalie Ferris, Stephanie Miles, John Martin of Natural England, Nick Edwards, Ruth Harding, Karen Wilkinson and Julian Woodman of Natural Resources Wales, and the Ministry of Defence/QinetiQ for access to ranges.

\section{References}

Ausden, M. 2007. Habitat Management for Conservation. Oxford: Oxford University Press.

Blackstock, T.H., Howe, E.A., Stevens, J.P., Burrows, C.R. \& Jones, P.S. 2010 Habitats of Wales: A comprehensive field survey. Cardiff: University of Wales.

Breeds, J. \& Rogers, D. 1998. Dune management without grazing - a cautionary tale. Enact. 6: 19-22. English Nature.

Carrington, D., Hurford, C., Jones, R.A. \& Pankhurst, T. 2010. The Fen Orchid - a species on the brink. British Wildlife 22: 1-8.

Currall, J.E.P. 1987. A transformation of the Domin scale. Vegetatio 72: 81-87.

DEFRA 2013. MAGIC [online] [Accessed 2 April 2020] Available at: http://www. natureonthemap.naturalengland.org.uk/MagicMap.aspx.

Dockerty G. 2010. Oxwich NNR Dune Gentian Survey 10/8/2010. Unpublished report, Countryside Council for Wales.

Elias, D.O. 1981. Gentianella amarella and uliginosa - Oxwich NNR 1979. Unpublished report, Nature Conservancy Council South Wales Region.

Evans, L.D.I. 2020. Current status of dune gentian Gentianella amarella subsp. occidentalis. MSc thesis, Manchester Metropolitan University.

Grootjans, A.P., Ernst, W.H.O. \& Stuyfzand, P.J. 1998. European dune slacks: strong interactions of biology, pedogenesis and hydrology. Trends in Ecology and Evolution 13: 96-100.

Grootjans, A.P., Geelen, H.W.T., Jansen, A.J.M. \& Lammerts, E.J. 2002. Restoration of coastal dune slacks in the Netherlands. Hydrobiologia 478: 181-203.

Grootjans, A.P., Adema, E.B., Bekker, R.M. \& Lammerts, E.J. 2004. Why young coastal dune slacks sustain such a high biodiversity'. In: Martinez, M.L. \& Psuty, N.P. (Eds). Coastal Dunes, Ecology and Conservation. Berlin: Springer-Verlag.

Hill, M.O., Preston, C.D. \& Roy, D.B. 2004. Plantatt. Huntingdon: Centre for Ecology and Hydrology. 
Holyoak, D.T. 1999. Gentianella uliginosa (Willd.) Boerner (Gentianaceae) rediscovered in North Devon. Watsonia 22: 428-429.

IUCN 2001. IUCN Red List Categories and Criteria: Version 3.1. Gland, Switzerland and Cambridge, U.K.: IUCN.

IUCN 2019. Standards and Petitions Committee. Guidelines for Using the IUCN Red List Categories and Criteria Version 14. Prepared by the Standards and Petitions Committee. [online] [Accessed 01 April 2020] Available at: http://www.iucnredlist.org/documents/RedListGuidelines.pdf.

Jones, R.A. 1992. Rare plant monitoring in Wales, 1991. Survey and monitoring report no. 93/2/4. Unpublished confidential report. Bangor: Countryside Council for Wales.

Jones, R.A. 1993. Rare plant monitoring in Wales, 1992. Survey and monitoring report no. 92/02/17. Unpublished confidential report. Bangor: Countryside Council for Wales.

Jones, R.A. 1994. Rare plant monitoring in Wales, 1993-1994. Survey and monitoring report no. 93/2/4. Unpublished confidential report June 1994. Bangor: Countryside Council for Wales.

Jones, P.S. 1998. Aspects of the population biology of Liparis loeselii (L.) Rich. var. ovata Ridd. ex Godfery (Orchidaceae) in the dune slacks of South Wales, UK, Botanical Journal of the Linnean Society 126: 23-139.

Jones, R.A. 1999. Gentianella uliginosa (Willd.) Boerner. In: Wigginton, M.J., ed. 1999. British Red data Books. 1 Vascular Plants. $3^{\text {rd }}$ ed. p. 176 . Peterborough: Joint Nature Conservation Committee.

Jones, M.L.M., Wallace, H.L., Norris, D., Brittain, S.A., Haria, S., Jones, R.E., Rhind, P.M., Reynolds, B.R. \& Emmett, B.A. 2004. Changes in vegetation and soil characteristics in coastal sand dunes along a gradient of atmospheric nitrogen deposition. Plant Biology 6: 598-605.

Kay, Q.O.N. 1973. The dune gentian in the Gower Peninsular. Nature in Wales 13: 81-85.

Kay, Q.O.N. \& John, R.F. 1995. The conservation of scarce and declining plant species in lowland Wales: population genetics, demographic ecology and recommendations for future conservation in 32 species of grassland and related habitats. Countryside Council for Wales Science report no. 110. March 1995. Countryside Council for Wales: Bangor.

Kleyer, M. 1999. Distribution of plant functional types along gradients of disturbance intensity and resource supply in an agricultural landscape. Journal of Vegetation Science 10: 697-708.

Lousley, J.E. 1950. The habitats and distribution of Gentiana uliginosa Willd. Watsonia 1: 279-282.

Morgan, V.M. 1988. Rare Plant Survey of West Glamorgan and Llanelli. Unpublished confidential reports 960 and 962. Chief Scientist's Directorate, Nature Conservancy Council.

Natural Resources Wales 2021. Sand of LIFE. [online] [Accessed 04 February 2021] Available at: https://naturalresources.wales/about-us/our-projects/natureprojects/sands-of-life/?lang=en

Olff, H., Huisman, J. \& Van Tooren, B.F. 1993. Species dynamics and nutrient accumulation during early primary succession in coastal sand dunes. Journal of Ecology 81: 693-706. 
Proctor, M.C.F. 2013. Vegetation of Britain and Ireland. London: HarperCollins.

Pugsley, H.W. 1924. Gentiana uliginosa Willd. in Britain. Journal of Botany 62: 193196.

Pye, K., Blott, S.J. \& Howe, M.A. 2014. Coastal dune stabilization in Wales and requirements for rejuvenation. Journal of Coastal Conservation 18: 27-54.

Rhind, P.M. \& Jones, P.S. 1999. The floristics and conservation status of sand-dune communities in Wales. Journal of Coastal Conservation 5: 31-42.

Rhind, P.M. \& Jones, R. 2009. A framework for the management of sand dune systems in Wales. Journal of Coastal Conservation 13: 15-23.

Rich, T.C.G. 1996. Is Gentianella uliginosa (Willd.) Börner present in England? Watsonia 21: 208-209.

Rich, T.C.G. 2004. [Gentianella uliginosa at] Pembrey Sands. Sanctuary 33: 93.

Rich, T.C.G. 2019. Dune gentian. 'Tim's botanical riches' YouTube channel. [online] Available at: https://youtu.be/dYjvj6Fbafo.

Rich, T.C.G. \& McVeigh, A. 2019. Gentians of Britain and Ireland. BSBI Handbook no 19. Harpenden: Botanical Society of Britain and Ireland.

Rich, T.C.G., McVeigh, A. \& Stace, C.A. 2018. New taxa and new combinations in the British flora. Edinburgh Journal of Botany 76: 173-180.

Rodwell, J.S. 2000. British Plant Communities Volume 5: Maritime communities and vegetation of open habitats. Cambridge: Cambridge University Press.

Rodwell, J.S. 2006. National Vegetation Classification users' handbook. Peterborough: Joint Nature Conservation Committee

Smart, S.M. 2000. Modular Analysis of Vegetation Information System (MAVIS). Plot Analyser Version 1.00. Merlewood, Cumbria: CEH.

Stace, C.A. 2019. New Flora of the British Isles. 4th ed. Middlewood Green, Suffolk: C. \& M. Floristics.

Sýkora, K.V., van den Bogert, J.C.J.M. \& Berendse, F. 2004. Changes in soil and vegetation during dune slack succession. Journal of Vegetation Science 15: 209-218.

Vaughan, I.M., Donovan, J.W. \& Warren Davis, T.A. 1972. Notes on the dune gentian. Nature in Wales 13: 33-36.

Wigginton, M.J., ed. 1999. British Red data Books. 1 Vascular Plants. $3^{\text {rd }}$ ed. Peterborough: Joint Nature Conservation Committee.

Willis, A.J. 1963. Braunton Burrows: The effects on the vegetation of the addition of mineral nutrients to the dune soils. Journal of Ecology 51: 353-374.

Youngson, J. 1986. The survival of the rare species Gentianella uliginosa in its natural habitats. Unpublished BSc thesis, Wolverhampton Polytechnic, Wolverhampton.

Copyright retained by author(s). Published by BSBI under the terms of the Creative Commons Attribution 4.0 International Public License.

ISSN: $2632-4970$

https://doi.org/10.33928/bib.2021.03.136 